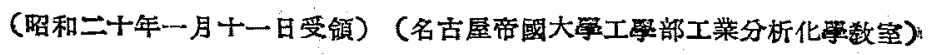

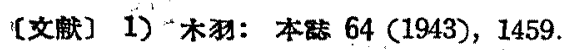

\title{
ハラフェニレンヂアミンとフォルムアルデとドとの 縮合による合成樹脂に就て
}

川口信太 郎

パラフェニレンヂミン 50 部, $28 \%$ フムモニア 50 部, $17 \%$ フォルマリン 100 部を加熱絈合 せしめて得られる樹脂は軟化點 $153^{\circ} \mathrm{C}$ で水, アルコール, ベンゼン, 三硫化类素, クロロフォル ム凡不溶. 濃酸溶液アニリン, ニトロベンゼン等に可溶である.
元素分析
C: $69.83 \%$
$\mathrm{H}: 6.50 \%$
$\mathrm{N}: 19.42 \%$
21.9
o: $4.26 \%$
I 式としての管算值.
67.2
6.8
4.2

21.9

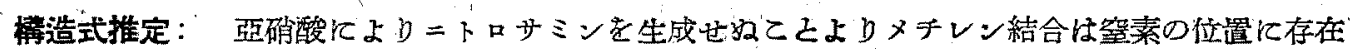

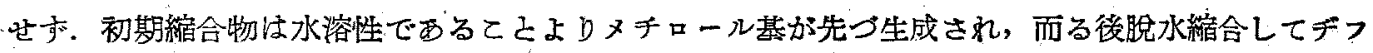
エニルメタン型さなる.

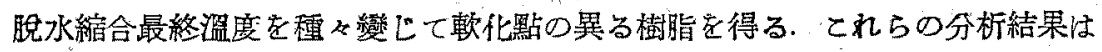

樹脂軟化㕫 $\left({ }^{\circ} \mathrm{C}\right)$

66

20

53
跮菜萲测值 (\%)

21.74 .

21.43

19.42
窒菜計算借 (\%)

I式として 21.87

I 式 $\times 2-\mathrm{NH}_{3} \quad 21.43$

$\mathrm{I}$ 式 $\times 2-2 \mathrm{NH}_{3} \quad 19.42$

郎ち加熱縮合の際江 2 個のアミノ基より $\mathrm{NH}_{3} 1$ 個放出して一NH一結合吉生するすの亡思考 さ礼る。<smiles>NC1CC(CC2CC(N)C(CC3CC(N)C(CC4CC(N)C(CC5CC(N)C(CO)CC5N)C(N)C4)CC3N)CC2N)C(N)CC1CO</smiles>

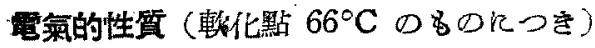

\begin{abstract}
弆面固有抵抗
娟積固有坻抗

誘電體損

$$
\tan \delta
$$

cycle
\end{abstract}

$\varepsilon$

$$
\begin{aligned}
& 2.1 \times 10^{15} \mathrm{ohms} \\
& 4.2 \times 10^{13} \mathrm{ohm} \mathrm{cm}
\end{aligned}
$$

$10^{\prime} \infty$

$25 \times 10^{-4}$

4.2
$10^{5} \infty$

$81 \times 10^{-4}$

4.1
$10^{7} \infty$

$633 \times 10^{-4}$

8.3

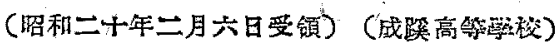

